\title{
5-Fluorouracil sensitizes colorectal tumor cells towards double stranded DNA breaks by interfering with homologous recombination repair
}

\author{
Upadhyayula Sai Srinivas ${ }^{1}$, Jerzy Dyczkowski², Tim Beißbarth², Jochen Gaedcke ${ }^{3}$, \\ Wael Y. Mansour ${ }^{4,5}$, Kerstin Borgmann ${ }^{4}$ and Matthias Dobbelstein ${ }^{1}$ \\ ${ }^{1}$ Institute of Molecular Oncology, University Medical Center Göttingen, Germany \\ 2 Department of Medical Stastics, University Medical Center Göttingen, Germany \\ ${ }^{3}$ Department of General, Visceral and Pediatric Surgery, University Medical Center Göttingen, Germany \\ ${ }^{4}$ Laboratory of Radiobiology \& Experimental Radiooncology, University Medical Center Hamburg-Eppendorf, Hamburg, \\ Germany \\ ${ }^{5}$ Tumor Biology Department, National Cancer Institute, Cairo University, Cairo, Egypt \\ Correspondence to: Matthias Dobbelstein, email: mdobbel@uni-goettingen.de
}

Keywords: colorectal cancer, radiochemotherapy, homologous recombination repair, 5-fluorouracil, Rad51

Received: November 19, $2014 \quad$ Accepted: March 11, 2015

Published: March 30, 2015

This is an open-access article distributed under the terms of the Creative Commons Attribution License, which permits unrestricted use, distribution, and reproduction in any medium, provided the original author and source are credited.

\section{ABSTRACT}

Malignant tumors of the rectum are treated by neoadjuvant radiochemotherapy. This involves a combination of 5-fluorouracil (5-FU) and double stranded DNA-break (DSB)-inducing radiotherapy. Here we explored how 5-FU cooperates with DSBinduction to achieve sustainable DNA damage in colorectal cancer (CRC) cells. After DSB induction by neocarzinostatin, phosphorylated histone 2AX ( $Y-H 2 A X)$ rapidly accumulated but then largely vanished within a few hours. In contrast, when CRC cells were pre-treated with 5-FU, gammaH2AX remained for at least 24 hours. GFP-reporter assays revealed that 5-FU decreases the efficiency of homologous recombination (HR) repair. However, 5-FU did not prevent the initial steps of HR repair, such as the accumulation of RPA and Rad51 at nuclear foci. Thus, we propose that 5-FU interferes with the continuation of HR repair, e. g. the synthesis of new DNA strands. Two key mediators of HR, Rad51 and BRCA2, were found upregulated in CRC biopsies as compared to normal mucosa. Inhibition of HR by targeting Rad51 enhanced DNA damage upon DSB-inducing treatment, outlining an alternative way of enhancing therapeutic efficacy. Taken together, our results strongly suggest that interfering with HR represents a key mechanism to enhance the efficacy when treating CRC with DNA-damaging therapy.

\section{INTRODUCTION}

Colorectal cancer (CRC) is the third most prevalent cancer type in the world [1] and fourth leading cause of cancer related deaths [2]. The cornerstone for the current treatment of rectal cancer, besides surgery, consists in radiochemotherapy i.e. combining anti-cancer drugs and ionizing radiation before and after the surgical removal of the tumor. Radiochemotherapy of colorectal cancers generally includes 5-fluorouracil (5-FU) in combination with $\gamma$-radiation.
5-FU is a base analogue that has been in use as an anti-cancer drug for nearly five decades [3]. Apart from $\mathrm{CRC}$, it is used for treating head and neck cancer and breast cancers and others [3]. 5-FU is metabolized upon cellular uptake resulting in (a) misincorporation of FdUTP into DNA, (b) misincoporation of FUTP into RNA and, (c) FdUMP mediated inhibition of thymidylate synthetase (TS).

Endogenous (e. g. reactive oxygen species) and exogenous (e. g. radiation or chemical mutagens) factors can cause DNA damage, and timely repair of the damaged 
DNA is necessary to maintain genomic stability. Errors during DNA replication lead to replication fork stalling and replicative stress, a condition particularly prevalent in tumor cells $[4,5]$. Overexpression or activation of genes that enhance proliferation, such as cyclin E and Ras [6, 7], or treatment with nucleoside analogs, hydroxyurea, or 5-FU [8-10] further exacerbate this stress condition [11]. Replicative stress represents a challenge to the stability of the genome; therefore, the identification and resolution of the damage in a replicating DNA are mandatory for cell survival. A cell accomplishes this by a complex and intricate signaling system known as the DNA damage response (DDR).

The DDR is a coordinated signaling cascade that is activated upon DNA damage and invokes a variety of proteins that help the cell to either repair the damaged DNA or to undergo apoptosis. Two key protein kinases, ATM and ATR, modulate the activity of a vast variety of proteins involved in the DDR. ATM primarily deals with double stranded DNA breaks, while ATR has been associated with single stranded DNA breaks and replicative stress signaling [12]. Around 700 substrates are believed to be phosphorylated by these two master regulatory kinases [13]. One of the substrates of ATM is $\mathrm{H} 2 \mathrm{AX}$, a histone $\mathrm{H} 2 \mathrm{~A}$ variant that constitutes around $10 \%$ of the total $\mathrm{H} 2 \mathrm{~A}$ in a cell [14]. On formation of DNA double strand breaks (DSB), it is phosphorylated at Ser139, and this phosphorylated H2AX is referred to as $\gamma$-H2AX.The phosphorylation of H2AX quickly spreads on the chromatin and can cover mega bases of DNA adjacent to the site of DNA damage [14].

Recently, studies have been conducted to elucidate the 5-FU-induced damage signaling in colorectal cancer derived cell lines. Treatment of HT-29 cells with 5-FU causes activation of Chk1 and Chk2 by ATR and ATM, respectively. HCT 116 cells, irrespective of their TP53 status, showed activation of ATM and Chk2; in HCT15 cells ATM was activated on treatment with high doses of 5-FU [15]. While these studies identified some of the 5-FU-induced damage signaling components, they do not clarify whether and how 5-FU is capable of sensitizing CRC cells towards double strand breaks, as resulting from ionizing radiation. However, such knowledge would be required to understand how 5-FU and irradiation cooperate in the clinical situation of neoadjuvant rectal cancer therapy.

The DDR often triggers repair mechanisms to remedy DNA damage. DNA double strand breaks are recognized by the MRN complex, which promotes the activation of ATM and the phosphorylation of H2AX and other signaling intermediates. Phosphorylated H2AX recruits proteins involved in DNA repair [16]. The DNA double strand breaks can be repaired either by homologous recombination repair (HRR) or the non-homologous end joining (NHEJ). The choice of the repair pathway depends the phase of the cell cycle in which the repair process is occurring and on regulatory factors like 53BP1 and BRCA1 [17, 18]. The fact that many cancers overexpress components of the HRR machinery [19-23] raises the possibility of targeting such components for cancer therapy.

In this study, we show that 5-FU in combination with neocarzinostatin (NCS) causes more sustained DNA damage than the single drugs. The combination also impaired the proliferation of CRC cells more severely than either drug alone. Furthermore, 5-FU reduced the repair of double strand DNA breaks by homologous recombination repair. The Rad51 inhibitor, B02 enhanced the efficacy of radiomimetic treatment similar to 5-FU, suggesting Rad51 inhibitors as alternative radiosensitizers.

\section{RESULTS}

\section{$\gamma-\mathrm{H} 2 \mathrm{AX}$ persists in cells treated with $5-\mathrm{FU}$ and neocarzinostain}

To model neo-adjuvant radiochemotherapy in cell culture, we treated colorectal cancer cells of the line SW480 or HeLa cells with a combination of the base analogue 5-FU and the radiomimetic neocarzinostatin (NCS). We pretreated the cells with $5 \mu \mathrm{M} 5$-FU for 24 $\mathrm{h}$ followed by addition of $100 \mathrm{ng} / \mathrm{ml} \mathrm{NCS}$ for 2, 8 and $24 \mathrm{~h}$ and immunoblot analysis (Figure 1A-1C). We found that the combination of 5-FU and NCS led to prolonged and persistent $\gamma-\mathrm{H} 2 \mathrm{AX}$ accumulation, even $24 \mathrm{~h}$ post NCS treatment. For cells treated with NCS alone, we observed a spike in the $\gamma$-H2AX levels at the $2 \mathrm{~h}$ time point which diminished over time, suggesting the repair of the damaged DNA (Figure 1B and 1C). Analogous results were obtained when using additional colorectal cancer cell lines, i. e. HCT116, SW837 and SW620 (Supplemental Figure S1, A-E). Next, we treated SW480 cells as above for $24 \mathrm{~h}$ and then stained $\gamma-\mathrm{H} 2 \mathrm{AX}$ in fixed cells by immunofluorescence, followed by quantification of the staining intensity by automated microscopy and image analysis (Figure 1D). Here again, we found persistent $\gamma-\mathrm{H} 2 \mathrm{AX}$ when combining 5-FU and NCS. A similar cooperation was observed when varying the concentrations of 5-FU (Figure S2A) and NCS (Figure $\mathrm{S} 2$, B-D). These observations raised the question how 5-FU prolongs the DNA damage induced by NCS; we suspected that 5-FU might interfere with the repair of double stranded DNA breaks and thereby increase the toxicity of DSBs. In order to evaluate the effect of 5-FU and NCS treatment on long term cell proliferation and survival, we monitored cell clonogenicity using bright field microscopy along with automated image analysis. As shown in Figure 1E, combined treatment with 5-FU and NCS severely reduced overall cell proliferation. On the other hand, single treatments with 5-FU and NCS allowed 


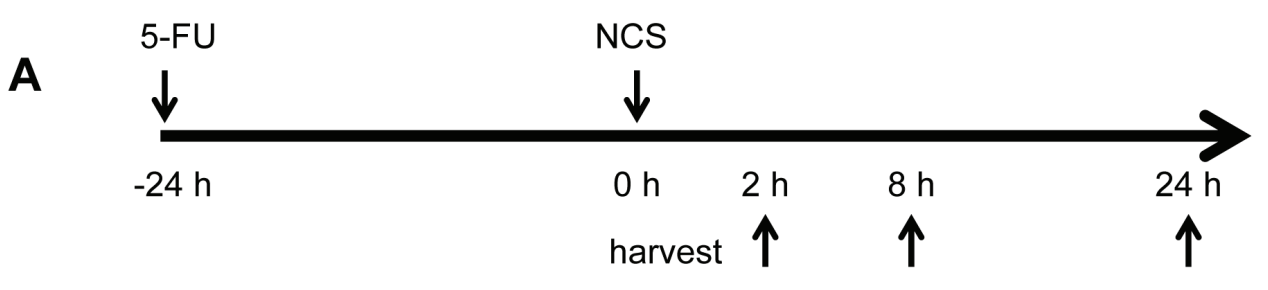

B

SW480

$\begin{array}{lcccccccccccc}\mathrm{t}(\mathrm{h}) & 2 & 8 & 24 & 2 & 8 & 24 & 2 & 8 & 24 & 2 & 8 & 24 \\ 5-\mathrm{FU} & - & - & - & + & + & + & - & - & - & + & + & + \\ \mathrm{NCS} & - & - & - & + & + & + & + & + & + & - & - & -\end{array}$

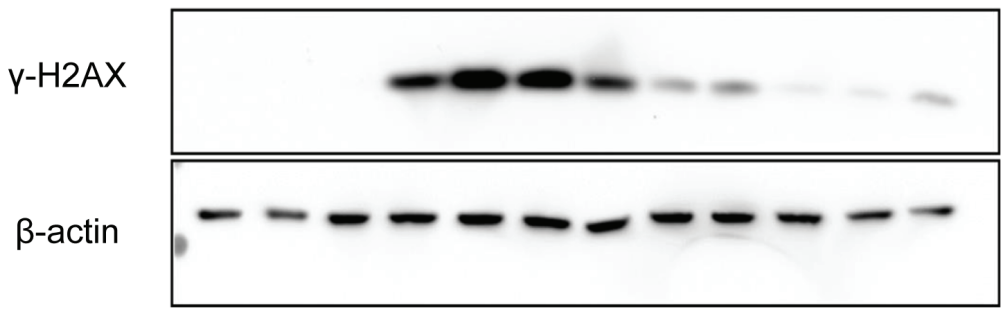

C

$\begin{array}{lcccccccccccc}\mathrm{t}(\mathrm{h}) & 2 & 8 & 24 & 2 & 8 & 24 & 2 & 8 & 24 & 2 & 8 & 24 \\ 5-\mathrm{FU} & - & - & - & + & + & + & + & + & + & - & - & - \\ \mathrm{NCS} & - & - & - & + & + & + & - & - & - & + & + & +\end{array}$

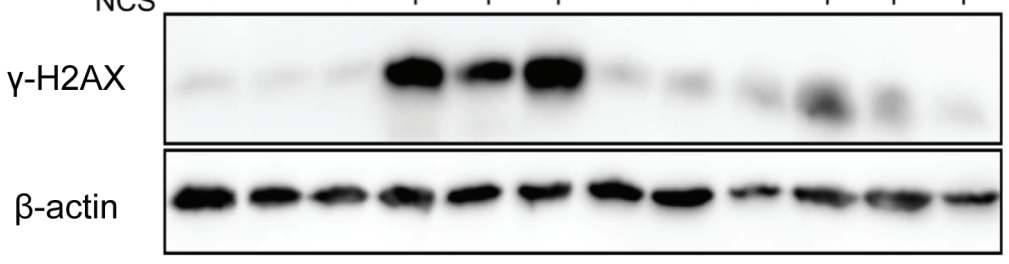

$\mathbf{D}$

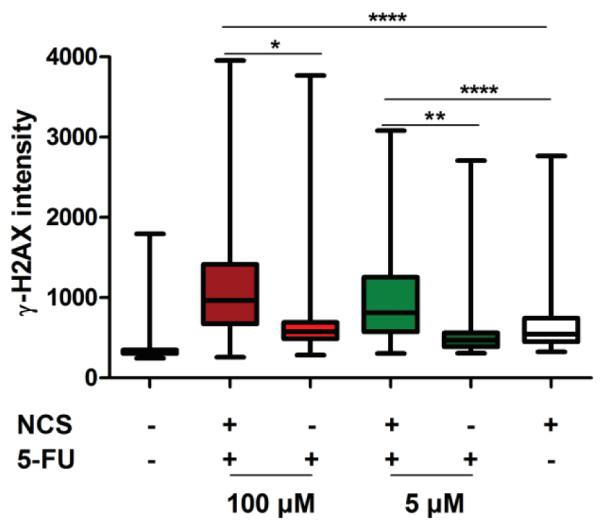

E

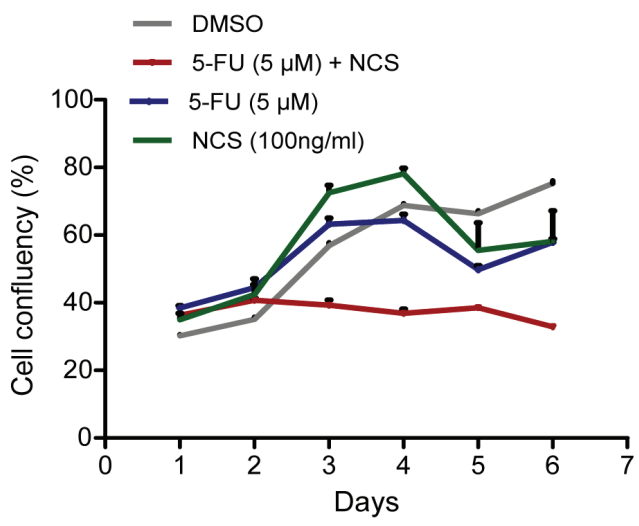

Figure 1: 5-FU in combination with NCS leads to persistent $\gamma$-H2AX accumulation and decreased survival. (A) Schematic representation of how the cells were treated. The cells were first incubated with $5 \mu \mathrm{M} 5$-FU for $24 \mathrm{~h}$ followed by treatment with $100 \mathrm{ng} / \mathrm{ml} \mathrm{NCS}$. The cells were then harvested at the indicated time points. (B) SW480 and (C) HeLa cells were treated as described with 5-FU and NCS. Whole cell extracts were immunoblotted, followed by detection of phosphorylated H2AX $(\gamma-\mathrm{H} 2 \mathrm{AX})$ and $\beta$-actin (loading control). (D) SW480 cells were treated with the indicated 5-FU concentrations for $24 \mathrm{~h}$ followed by NCS for $24 \mathrm{~h} . \gamma$-H2AX intensities were determined in single cells by immunofluorescence and automated microscopy. The fluorescence intensities of at least 1000 cells per sample were determined by digital image analysis and are shown in boxplots to indicate the $10^{\text {th }}, 25^{\text {th }}, 50^{\text {th }}, 75^{\text {th }}$ and $90^{\text {th }}$ percentiles $(n=3)$. (E) SW480 cells were treated as described in (D). Cell confluency was measured at regular intervals of $24 \mathrm{~h}$ using automated microscopy. 
cells to recover upon removal of the drug. This indicated that the damage induced by the combination of 5-FU and NCS is severe and more sustainable than upon single drug treatment.

\section{Homologous recombination repair is reduced upon 5-FU treatment}

NCS, like $\gamma$-radiation, primarily induces double strand DNA breaks. The persistent accumulation of $\gamma$-H2AX suggested that 5-FU might interfere with at least one of the principal repair mechanisms for DSBs, HRR or NHEJ. To assess this directly, we carried out plasmid based reporter assays. These assays are based on the repair of a GFP-encoding DNA upon transfection of reporter plasmids $[24,25]$. Strikingly, we found that 5-FU reduces homologous recombination repair (Figure 2A-2B). In contrast, we did not observe any significant change in NHEJ efficacy upon treatment with either 5-FU or NCS (Figure 2C-D). We conclude that 5-FU treatment reduces the efficiency by that a cell carries out HRR, whereas the mechanisms of NHEJ remain largely unaffected.

\section{5-FU treatment does not impair recruitment of RPA2 or Rad51}

In principle, impaired factor recruitment could represent one reason for reduced HRR. One group of such factors is represented by the RPA complex. We therefore assessed the recruitment of RPA2, a subunit of the RPA complex, to see if 5-FU treatment interferes with early stages of HRR. 5-FU did not impair the recruitment of RPA2 to the intranuclear structures, as indicated by the foci formation of RPA2 detected by immunofluorescence and digital image analysis (Figure $3 \mathrm{~A}$ and $3 \mathrm{~B}$ ). On the contrary, treatment with 5-FU and NCS together led to an increase in RPA2 foci formation $2 \mathrm{~h}$ post NCS treatment. The more pronounced foci formation $2 \mathrm{~h}$ post NCS treatment is in accordance with the extensive DNA damage induced by 5-FU in combination with NCS. At longer times post NCS treatment, i. e. 8 and $24 \mathrm{~h}$, cells that were pretreated with 5-FU showed even more pronounced RPA2 foci and more discrete colocalization with $\gamma-\mathrm{H} 2 \mathrm{AX}$ (Supplemental Figure S3 A-C). It can therefore be concluded that 5-FU does not impair the recruitment of RPA2. We next investigated the recruitment of Rad51, a key component of HRR, in response to treatment with 5-FU and NCS (Figure 3C and 3D, and Supplemental Figure S4). Treatment with NCS alone led to the formation of Rad51 foci that mostly colocalized with $\gamma-\mathrm{H} 2 \mathrm{AX}$ foci at $2 \mathrm{~h}$ post treatment and increased further at $8 \mathrm{~h}$ post treatment before being reduced to near-background levels $24 \mathrm{~h}$ post treatment. In contrast, treatment with a combination of 5-FU and NCS gave rise to sustained Rad51 foci $24 \mathrm{~h}$ post NCS treatment. We conclude that
5-FU does not impair the recruitment of repair proteins, like RPA2 and Rad51. This suggests that 5-FU-induced HRR inhibition does not occur through interference with the early steps of HRR.

\section{Reduced homologous recombination is not caused by loss of cells in S or G2 phases of the cell cycle}

Double strand break repair processes are cell cycle dependent. Most of the NHEJ is restricted to the G1 phase, while HRR is active in the S and G2 phases [26]. We therefore assessed whether the reduction in homologous recombination was a consequence of a shift in the cell cycle phase distribution upon treatment with 5-FU. To this end, we performed propidium iodide staining and flow cytometry of SW480 cells (Figure 4A) and found that 5-FU actually increases the proportion of cells in $\mathrm{S}$ phase (Figure 4B). This was further confirmed by the detection of DNA synthesizing cells through 5-ethynyl2'deoxyuridine (EdU) incorporation. Indeed, 5-FU treatment increased the fraction of EdU positive cells (Figure 4C) This indicated that the observed reduction in HRR upon 5-FU treatment did not occur due to arrest of the cells in an unfavorable cell cycle phase. The accumulation of cells in S phase upon 5-FU treatment is compatible with active HRR. Nonetheless, 5-FU leads to a reduction in this repair process, possibly through interference with DNA polymerization during HRR.

\section{Antagonizing homologous recombination repair by a Rad51 inhibitor also leads to persistence of DNA damage}

Among the proteins involved in homologous recombination repair, $\operatorname{Rad} 51$ and $\mathrm{BRCA} 2$ represent is a key modulators. As a first step to assess their importance in CRC, we determined the RNA levels corresponding to these genes by microarray hybridization of 181 CRC biopsy samples in direct comparison with 215 normal mucosa biopsies. And indeed, both Rad51 and BRCA2 expression levels were upregulated in the tumors to a highly significant extent (Figure 5A-5B; refer Supplemental Table S1 for raw data and patient characteristics). No significant relation was observed between the tumor grade, and expression of Rad51 or BRCA2 (Supplemental Figure S5). The mRNA expression levels of Rad51 and BRCA2 were highest in S phase of the cell cycle (Supplemental Figure S6). Since many tumors contain a high proportion of dividing cells, S-phaseassociated expression may partially explain why Rad51 and BRCA2 levels are high in tumors. In any case, HR mediators are enhanced in CRCs and may thus support $\mathrm{CRC}$ progression. This prompted us to test whether direct HR inhibitors may sensitize CRC cells towards DSBs, as 5-FU does. To this end, we firstly depleted Rad51, a 
A
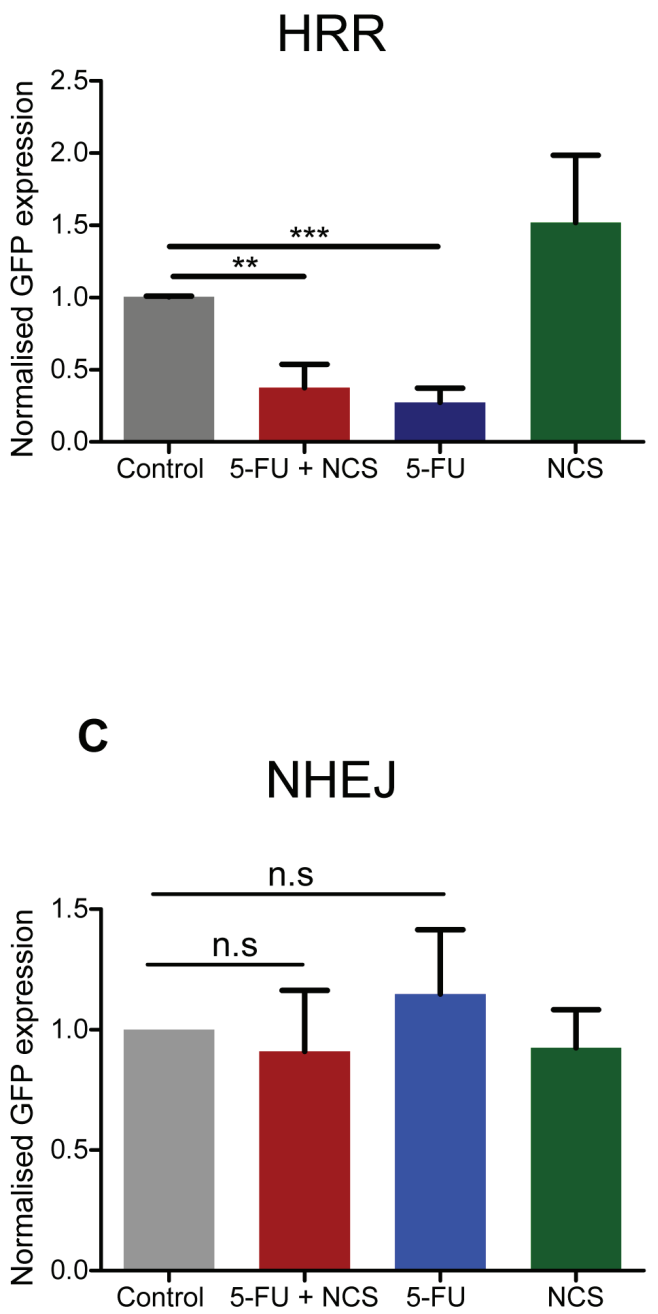

B

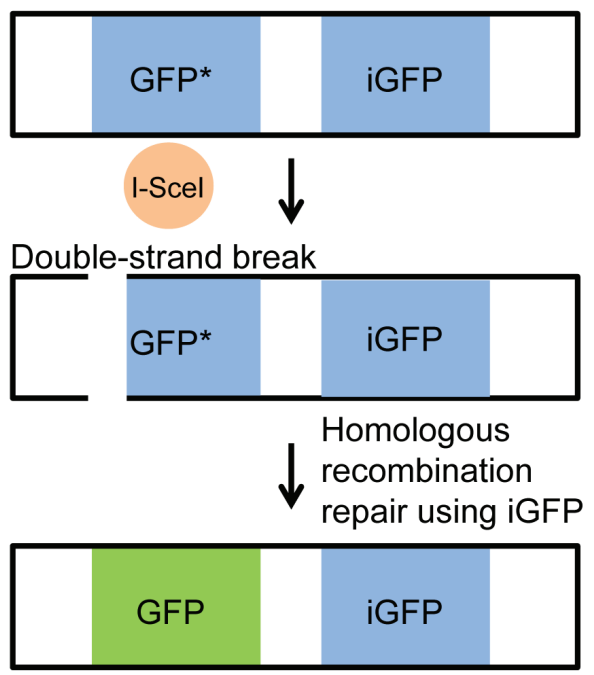

D

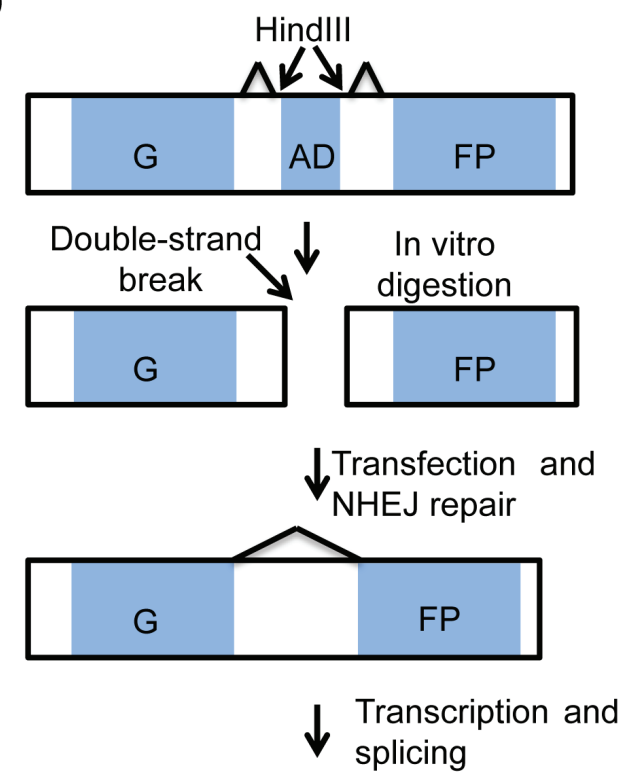

\section{GFP}

Figure 2: 5-FU reduces the homologous recombination repair. (A) DRGFP assay to assess the HRR. The normalized GFP intensity, as determined by flow cytometry upon transfection of reporter plasmids, to assess the activity of HRR upon drug treatment. GFP positive cells were measured using flow cytometer and normalized to the control. Note that these assays require extreme transfection efficiencies and were therefore performed only in HeLa cells. (B) Schematic representation of the DRGFP assay. The plasmid contains two non-functional, truncated GFP cassettes. The cassette at the 5' end has an I-SceI restriction endonuclease cleavage site. The synthesis of I-SceI in the cell by the virtue of a closed circular transfected expression plasmid produces a double strand break in the GFP cassette as shown. If the cell uses the GFP cassette at the 3' end (iGFP) to repair the double strand break using HRR a functional GFP cassette is generated. (C) NHEJ assay in analogy to A. GFP positive cells were measured using a flow cytometer and normalized to the control. Note that these assays require extreme transfection efficiencies and were therefore performed only in HeLa cells (D) Schematic representation of the NHEJ assay. The NHEJ plasmid contains two exons that together encode GFP, separated by an adenovirus derived (AD) exon. The Hind III restriction endonuclease sites are present on either side of the $\mathrm{AD}$ exon, as depicted in the figure. The plasmid was first digested with Hind III in vitro and then transfected in to HeLa cells. If the cell repairs the damage using NHEJ, the splice donors and acceptor sites are so placed that a functional GFP transcript is produced. Results from at least three independent experiments are shown with columns representing the standard error of the mean. 
A

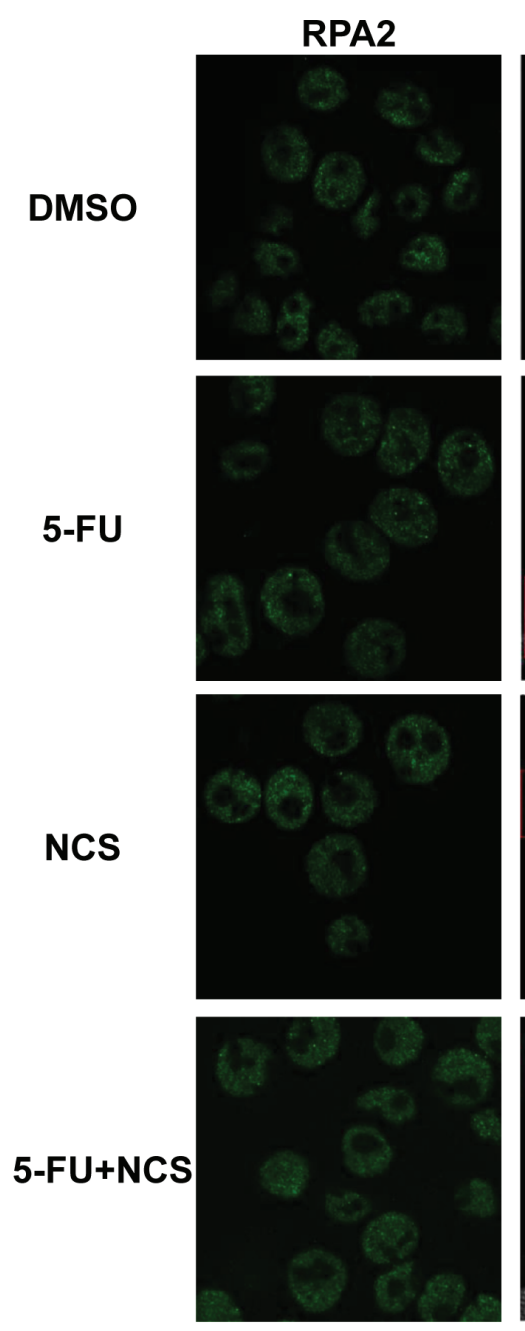

B

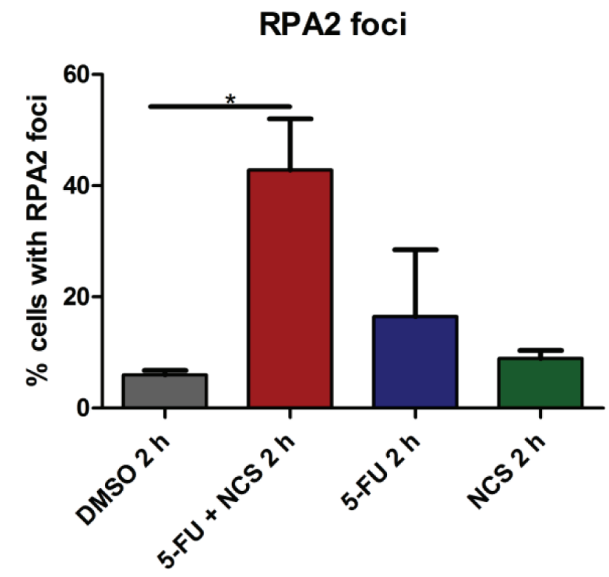

C
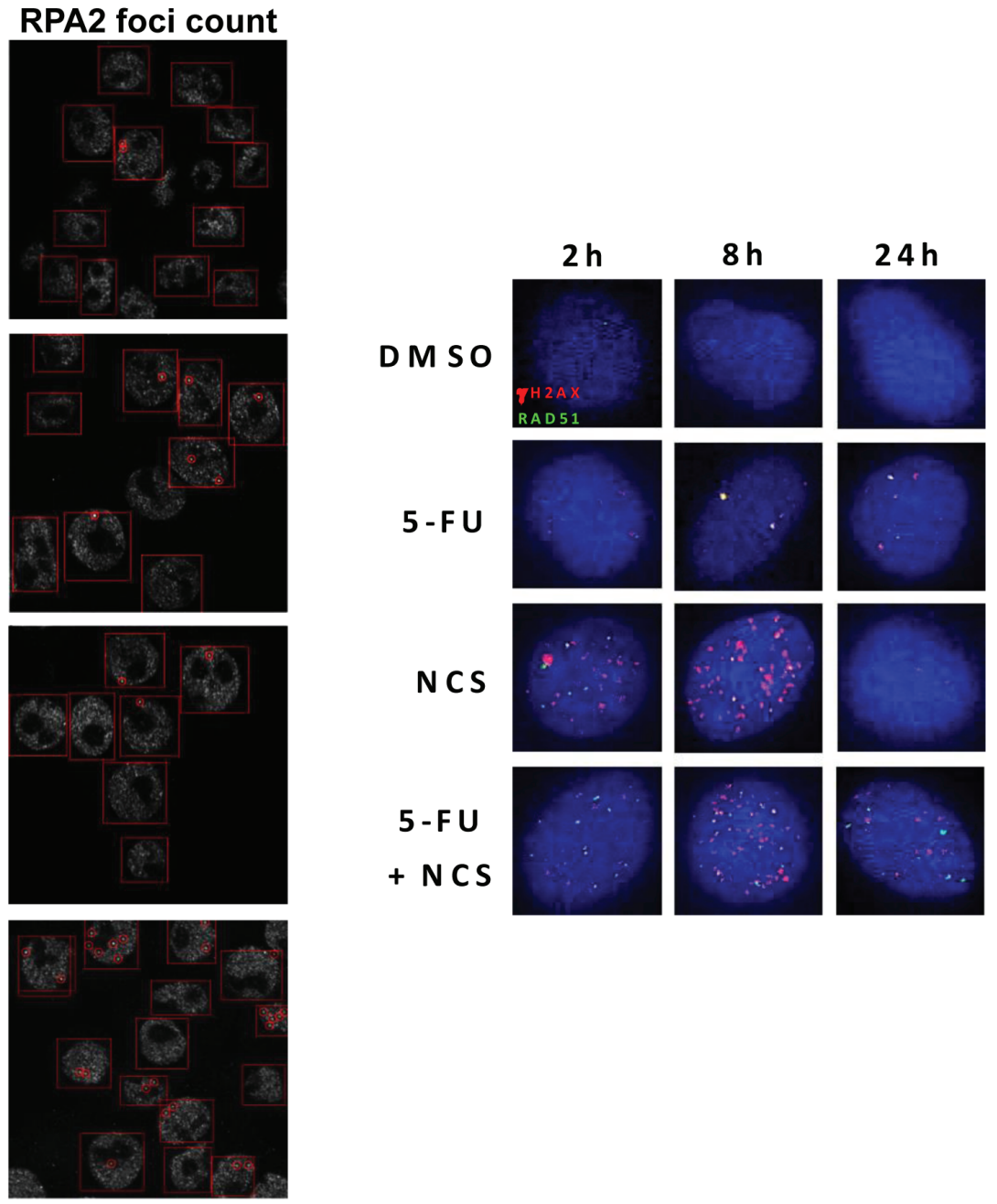

D

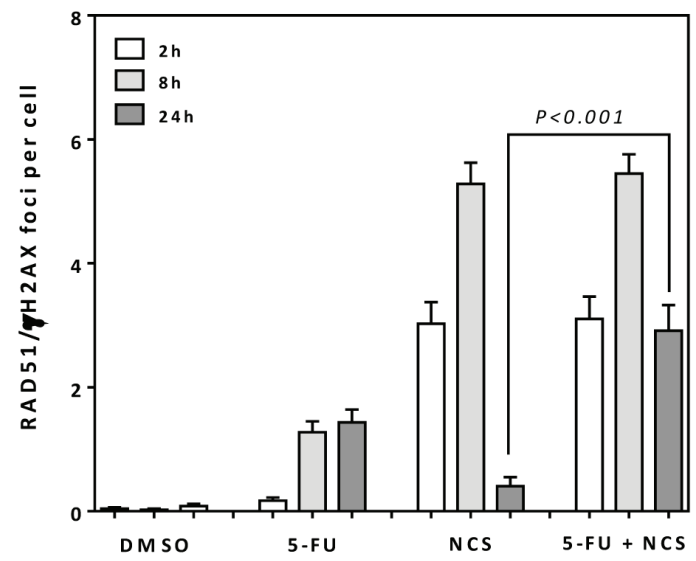

Figure 3: 5-FU and/or NCS do not decrease the recruitment of RPA2 and Rad51. (A) Confocal microscopy images of SW480 cells treated with, DMSO, $5 \mu \mathrm{M} 5-\mathrm{FU}+100 \mathrm{ng} / \mathrm{ml} \mathrm{NCS}, 5 \mu \mathrm{M} 5-\mathrm{FU}$, and $100 \mathrm{ng} / \mathrm{ml} \mathrm{NCS}$ for $2 \mathrm{~h}$ (B) RPA2 foci were counted in at least 100 cells per sample per experiment $(\mathrm{n}=3)$, and the percentage of cells containing detectable foci were plotted as a histogram. The RPA2 foci were counted using the FociCounter software, (C) Representative IF images for Rad51 colocalized with $\gamma \mathrm{H} 2 \mathrm{AX}$ foci at the indicated time points after treatment with DMSO, $5 \mu \mathrm{M} 5-\mathrm{FU}+100 \mathrm{ng} / \mathrm{ml} \mathrm{NCS}, 5 \mu \mathrm{M} 5-\mathrm{FU}$, and $100 \mathrm{ng} / \mathrm{ml} \mathrm{NCS}$ for 2, 8 and $24 \mathrm{~h}$, (D) Quantification of Rad51 colocalized with $\gamma \mathrm{H} 2 \mathrm{AX}$ foci counted in at least 100 cells each at the indicated time points. Error bars represent the SEM of two independent experiments. 


\section{A}

$t(h)$
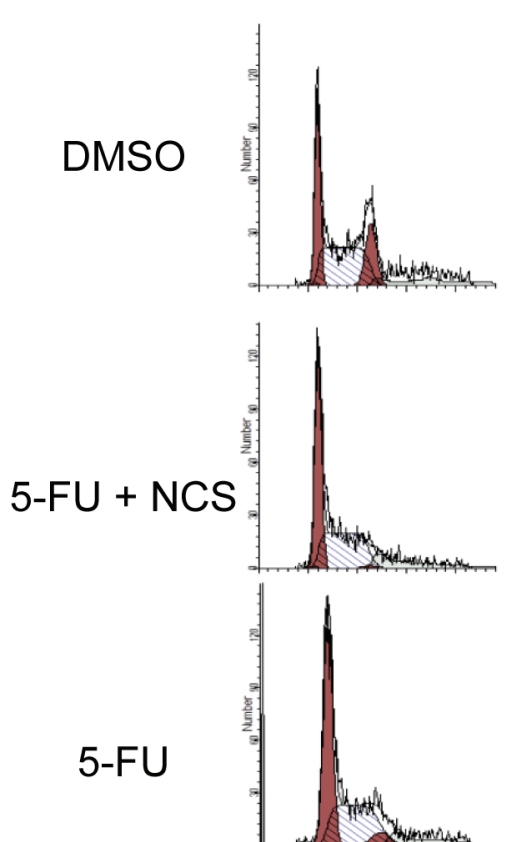

NCS

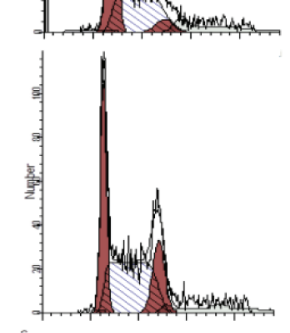

8
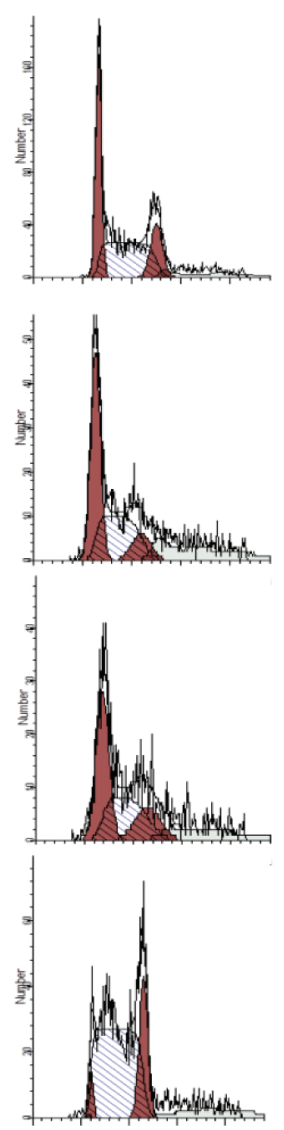

24
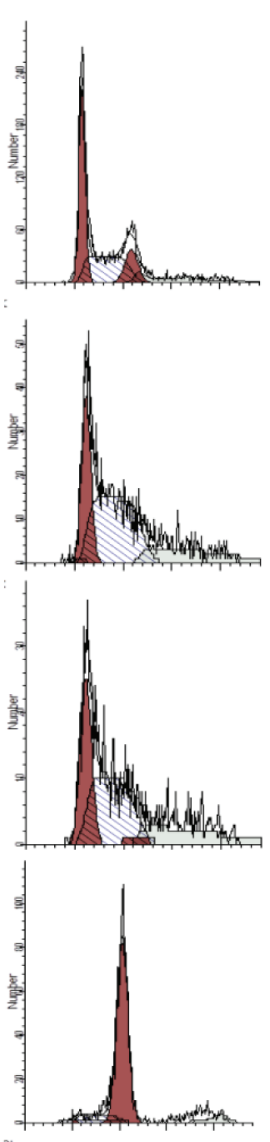

DNA content
B

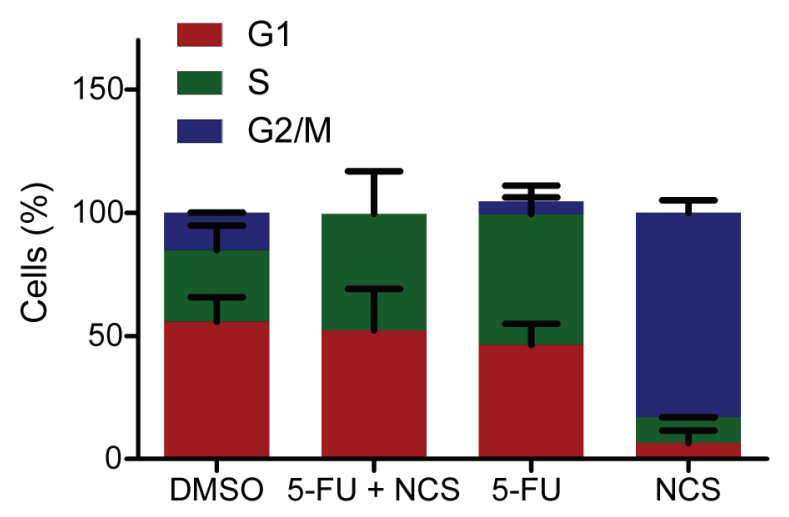

C

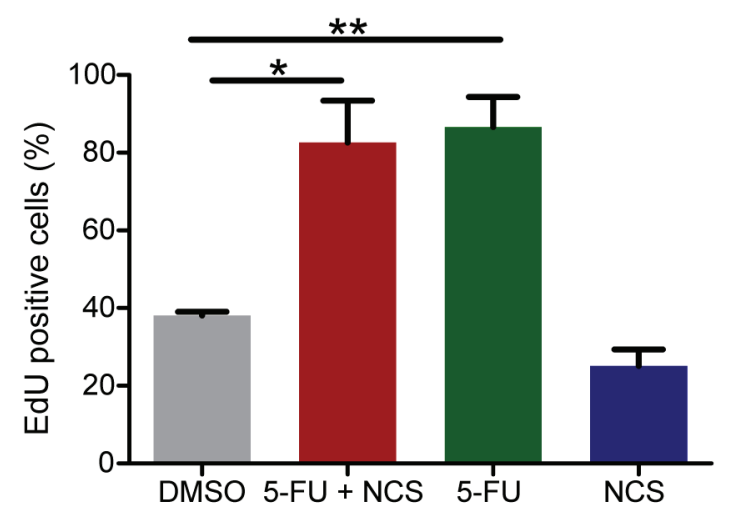

Figure 4: Reduced HRR is not a consequence of a shift in cell cycle distribution. (A) Propidium iodide staining and flow cytometry of SW480 cells treated with DMSO, $5 \mu \mathrm{M} 5$-FU and/or $100 \mathrm{ng} / \mathrm{ml} \mathrm{NCS}$ as detailed in Figure 1A. (B) Quantification of the cell cycle distribution. (C) EdU assay in SW480 cells to determine the percentage of cells in S phase. The cells were first treated as shown in Figure 1A; $2 \mathrm{~h}$ prior to fixation, $15 \mu \mathrm{M}$ EdU was added to the cells. The cells were then fixed on the plate, and EdU was detected by Alexa 488 azide. Fluorescence intensity was quantified as described for $\gamma-\mathrm{H} 2 \mathrm{AX}$ in Figure 1C. 
principal mediator of $\mathrm{HR}$, and found that this strongly augmented the levels of $\gamma-\mathrm{H} 2 \mathrm{AX} 24 \mathrm{~h}$ after NCS treatment (Figure 5C). Next, we employed the newly developed Rad51 inhibitor B02 [27]. We treated CRC cells with B02, with or without co-treatment with NCS and analyzed the accumulation of $\gamma$-H2AX (Figure 5D). We found that cells treated with B02 and NCS showed a strong accumulation of $\gamma$-H2AX; however, cells treated with B02 alone did so too. Since it has been previously reported that apoptosis can cause accumulation of $\gamma-\mathrm{H} 2 \mathrm{AX}$, we next determined the extent of B02- induced apoptosis by detecting cleaved caspase 3. We found that treatment with B02 alone was sufficient to induce apoptosis (Figure 5). To distinguish this caspase-mediated $\gamma-\mathrm{H} 2 \mathrm{AX}$ accumulation from immediate DDR, we inhibited caspase activity by ZVADFMK. On simultaneous treatment of cells with B02 and ZVAD-FMK, apoptosis was reduced, as seen by lack of cleaved caspase 3 . We now probed for the accumulation of $\gamma-\mathrm{H} 2 \mathrm{AX}$ under these new conditions and found that treatment with B02 alone did not lead to any detectable $\gamma-\mathrm{H} 2 \mathrm{AX}$ accumulation. Importantly however, treatment with B02 and NCS caused massive $\gamma-\mathrm{H} 2 \mathrm{AX}$ accumulation similar to the combination of 5-FU and NCS together, even when the caspases were blocked (Figure 5D). These results strongly argue that Rad51 inhibition hinders the repair of ds DNA breaks. This raises the perspective of using Rad51 inhibitors to radiosensitize rectal cancer cells, especially in the context of cancer cell resistance towards 5-FU.

\section{DISCUSSION}

Our results strongly suggest that 5-FU sensitizes colorectal cancer cells towards double stranded DNA breaks (DSBs), by interfering with the repair of such lesions. This finding provides a rationale for the widely used radiochemotherapy regimen, including 5-FU and ionizing irradiation, and applied as a neoadjuvant strategy to treat rectal cancer. Mechanistically, 5-FU interferes with homologous recombination repair (HRR) but not nonhomologous end joining (NHEJ) (Figure 2). Although a majority of 5-FU-treated cells remains in cell cycle phases where the HRR machinery would be available to the cell (Figure 4), this repair pathway still fails to eliminate DNA damage. Indeed, 5-FU-treated cells, when exposed to a DSB-inducing agent, accumulate RPA2 at the damaged site (Figure 3), but nonetheless, the lesions persist. We therefore propose that 5-FU does not block the assembly of the HRR machinery but instead interferes with the subsequent steps of HRR. Namely, the polymerization of DNA in the course of HRR may be hampered by the misincorporation of 5-FU metabolites (5F-dUTP), or by perturbing the balance of nucleotide pools through the inhibition of thymidylate synthetase [3].

Interestingly, we observed that, although 5-FU interferes with HRR (Figure 2A), it affects long term cell proliferation only mildly (Figure 1E), while a combination of 5-FU and NCS severely impairs it (Figure 1E). These results can be viewed as evidence that 5-FU-induced DNA damage is low and does not challenge the cellular repair machinery with irreparable DNA damage. On the other hand, the 5-FU-induced reduction in HRR makes it impossible for the cell to meet the need of repair when extensive double strand DNA breaks are induced by NCS; this then results in prolonged DNA damage (Figure 1B1D), and impaired cell proliferation (Figure 1E). This also suggests that the transient suppression of HRR by 5-FU is as such well tolerated by tumor cells, but sensitizes them towards the additional induction of double strand DNA breaks. Our results also give credence to the presently used clinical regimen of combining 5-FU based chemotherapy with radiation.

These results not only provide an explanation why combining 5-FU with ionizing irradiation in cancer treatment. On top of this, the findings reported here suggest an alternative approach to radiosensitization, especially when cancer cells are found resistant against 5-FU. Resistance gained to 5-FU can be attributed to multiple actors like overexpression of thymidylate synthetase (TS) for overcoming the inhibition by 5-FU, Bcl-2 and Bcl-XL [28] protecting cells from 5-FU-induced apoptosis, or lack of mismatch repair (MMR) factors [29]. In such cases, and according to our results, blocking Rad51 by specific inhibitors appears as a valid alternative to achieve radiosensitization, at least in case of a successful clinical development of Rad51 inhibitors. In addition, however, Chk1/Chk2 inhibitors may also turn out suitable to interfere with HRR and hence for radiosensitization, as has been reported previously. AZD7762, a Chk1 inhibitor prevents the formation of $\operatorname{Rad} 51$ foci in pancreatic carcinoma cells [30] and also leads to persistent $\gamma-\mathrm{H} 2 \mathrm{AX}$ in response to $\gamma$-radiation. Rad51 is phosphorylated at Thr 309 by Chk1 [31], facilitating its recruitment to the sites of DSBs which may explain why Chk1 inhibition reduces HRR efficiency. Interfering with DNA repair mechanisms appears to represent a broadly applicable route to improve cancer therapy, as has been recently reviewed [32]. Along this line, 5-FU has previously been found to interfere with additional repair pathways as well, in particular base excision repair and mismatch repair [33]. Thus, it is conceivable that 5-FU exerts at least a proportion of its cytotoxic effects, alone or in combination with additional therapeutics, by interfering with multiple DNA repair pathways.

If interfering with HRR radiosensitizes tumor cells, this raises the question whether the levels and activity of HRR mediators might serve as predictive markers for radio- and chemosensitivity. And indeed, our results show that colorectal cancers express higher levels of Rad51 and BRCA2 than normal mucosa (Figure 5). This upregulation can be understood as a compensatory mechanism, selected for due to generally enhanced spontaneous DNA damage 
A

Rad51

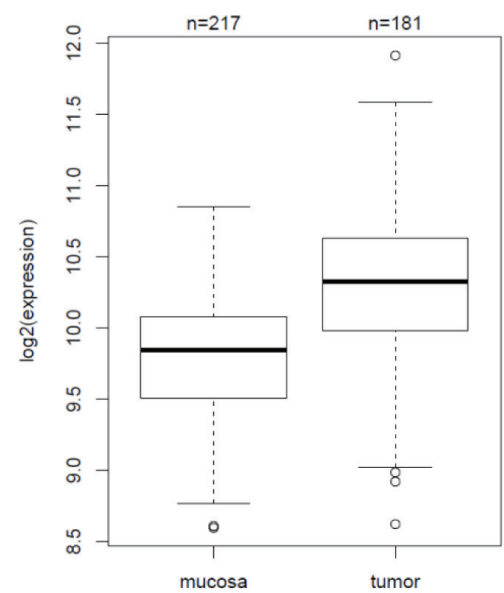

$p=9.2 e-18$, one sample t-test

B

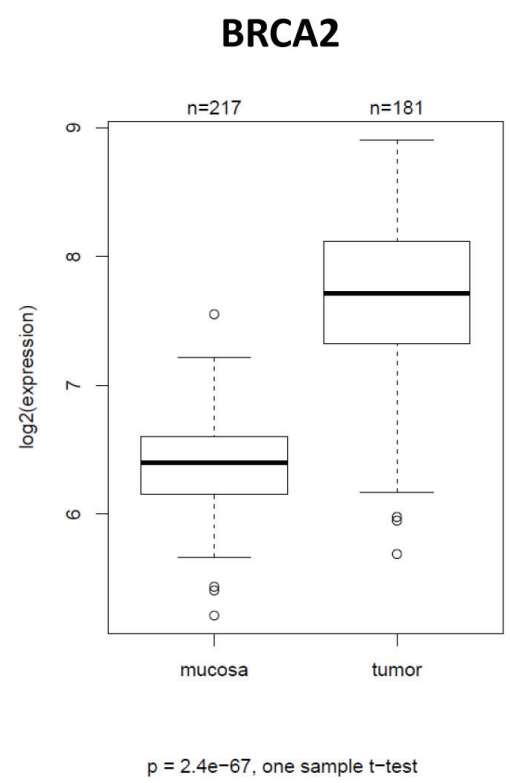

C

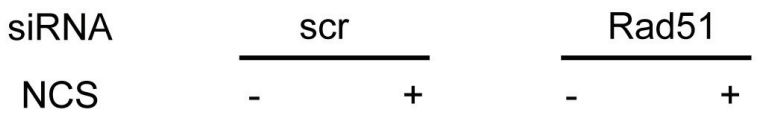

Rad51

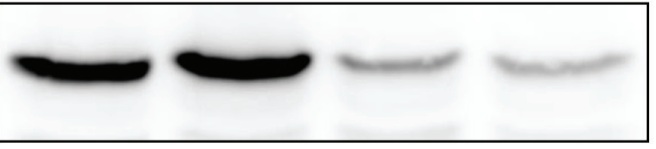

$\mathrm{Y}-\mathrm{H} 2 \mathrm{AX}$

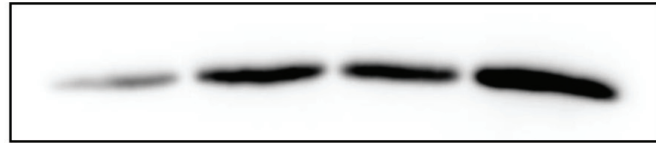

$\beta$-actin

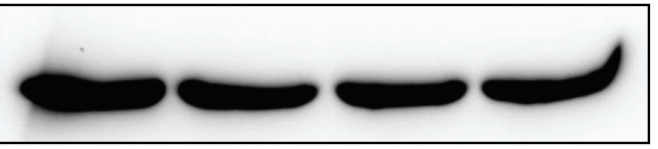

D

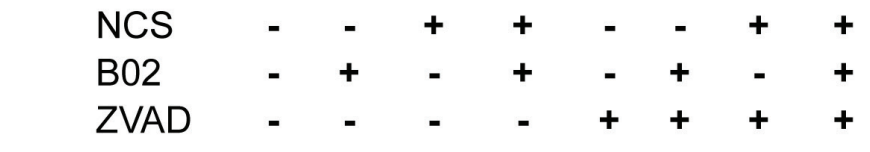

cleaved

Caspase 3

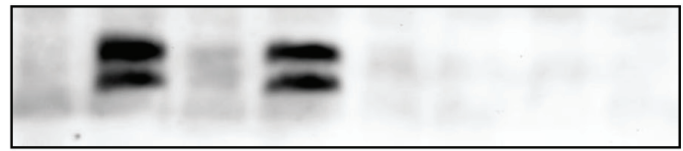

$\mathrm{Y}-\mathrm{H} 2 \mathrm{AX}$

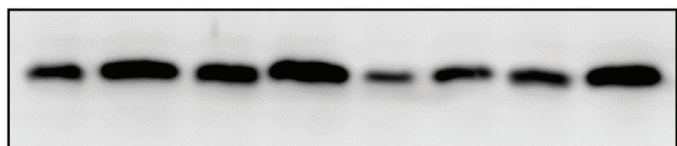

$\beta$-actin

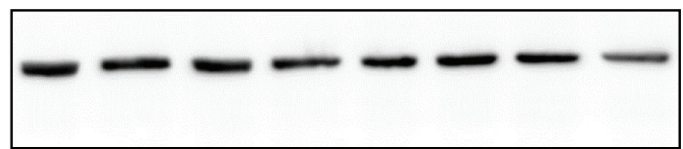

Figure 5: Inhibition or knockdown of Rad51 also leads to persistent $\boldsymbol{\gamma}$-H2AX. mRNA expression of HRR components in tumors and normal mucosa evaluated in biopsy material from human specimens using microarray hybridization (A) Rad51 and (B) BRCA2. (C) SW480 cells were depleted of Rad51 using siRNA for $16 \mathrm{~h}$ and then treated with NCS for $24 \mathrm{~h}$. Whole cell extracts were immunoblotted followed by detection by the indicated antibodies. (D) SW480 cells were treated with B02 and/or ZVAD for $24 \mathrm{~h}$ followed by NCS for 24 $\mathrm{h}$. Whole cell extracts were immunoblotted, followed by detection by the indicated antibodies. $\beta$-actin was used as a loading control. 
in most cancer cells [34]. However, it remains to be determined whether these expression levels in tumor cells also correlate with the response to radiochemotherapy. Rad51 overexpression showed inverse correlation with survival in patients with colorectal cancer and head and neck cancer perhaps arguing against a direct role in tumor cell resistance to therapy $[35,36]$. However, higher levels of Rad51 were found to be associated with enhanced tumor grading of invasive breast ductal breast cancer [20]. Recently, overexpression of Rad51 was found as a negative predictive marker for neoadjuvant therapy using cisplatin/5-FU to treat esophageal cancers again arguing that high Rad51 levels may confer tumor cell resistance towards DNA damaging drugs [37].

Taken together, our results point out that we are already interfering with DNA repair mechanisms for cancer therapy when using conventional chemotherapeutics. Apparently, DNA repair is blocked by 5-FU, and this contributes to the success of radiotherapy. By adding to our understanding on how DNA repair modulates radio- and chemosensitivity, the development of more targeted repair inhibitors may enable greater efficacy and specificity of sensitization. One example for such a strategy appears to consist in the direct inhibition of HRR to improve the neoadjuvant therapy of rectal cancer.

\section{EXPERIMENTAL PROCEDURES}

\section{Cell culture, transfection, chemicals and treatments}

HeLa and SW480 cells were cultured in Dulbecco's modified Eagle's medium (DMEM) and RPMI 1640, respectively (Invitrogen) supplemented with 10\% fetal calf serum and antibiotics. For siRNA-mediated knockdown, cells were reverse transfected with $10 \mathrm{nM}$ pre-designed Silencer Select siRNAs (Invitrogen) using Lipofectamine 2000 (Invitrogen). Cells were treated with the chemotherapeutics, 5-Fluorouracil (5-FU, F6627, SigmaAldrich), Neocarzinostatin (NCS, N9162, Sigma -Aldrich), B02 (SML 0634, SigmaAldrich), and ZVADFMK (V116, SigmaAldrich). The samples treated with the Dimethyl sulfoxide (DMSO, A3672, Applichem) served as negative controls.

\section{Immunoblotting and antibodies}

Cell lysates were separated by SDS polyacrylamide gel electrophoresis and transferred to nitrocellulose membranes. For detection of specific proteins, the membranes were incubated with antibodies diluted in tris-buffered saline (TBS) containing 0.1\% Tween-20 and $5 \%$ bovine serum albumin (BSA). The following primary antibodies were used: mouse anti- $\gamma$-H2AX (JBW301,
Millipore, Merck), mouse anti- $\beta$-actin (AC-15, Abcam), mouse anti-HSC70 (B-6, Santa Cruz Biotechnology), rabbit anti cleaved Caspase 3 (9664, Cell signaling), rabbit anti-Rad51 (H92, Santa Cruz Biotechnology). Primary antibodies were detected with peroxidase-coupled secondary antibodies (Jackson, ImmunoResearch Europe).

\section{Proliferation assay}

For cell proliferation analysis, cells were grown in 96-well plates and treated with $5 \mu \mathrm{M} 5-\mathrm{FU}$ for $24 \mathrm{~h}$, followed by addition of $100 \mathrm{ng} / \mathrm{ml} \mathrm{NCS}$ and further incubation for $24 \mathrm{~h}$. Then the drugs were removed and cell confluency was monitored every $24 \mathrm{~h}$ the using Celigo, an automated microscopy device (Cyntellect). The media was changed every $48 \mathrm{~h}$.

\section{Flow cytometry}

For flow cytometry studies of cell cycle progression, cells were harvested, fixed in $70 \%$ ethanol and stained with propidium iodide (PI, P4864, Sigma-Aldrich). Samples were then analysed by a Guava EasyCyte Plus system (Millipore, Merck) and the ModFit LT ${ }^{\mathrm{TM}}$ software (Verity Software House).

\section{DRGFP and NHEJ assay}

HeLa cells were cultured in 6 well plates to a confluency of $80 \%$ and transfected with the plasmids DRGFP or NHEJ $(1.1 \mu \mathrm{g})$ pCBASce1 for HRR $(1.1 \mu \mathrm{g})$ each combined with DsRed (100 ng) by lipofectamine 2000 for normalization. $4 \mathrm{~h}$ after transfection, fresh media was added and cells were treated with $5 \mu \mathrm{M} 5$-FU/DMSO for $24 \mathrm{~h}$. This was followed by treatment with $100 \mathrm{ng} / \mathrm{ml}$ NCS for $24 \mathrm{~h}$ while maintaining the treatment with 5-FU. Following treatment, the cells were harvested, suspended in PBS, and GFP as well as RFP expression was measured by flow cytometry using the Guava EasyCyte Plus system (Millipore, Merck).

\section{Immunofluorescence microscopy and quantitative assesment}

Cells were grown in 96 well plates (Becton Dickinson) for $24 \mathrm{~h}$ and then treated with $5 \mu \mathrm{M} 5$-FU for $24 \mathrm{~h}$ followed by addition of $100 \mathrm{ng} / \mathrm{ml} \mathrm{NCS}$ and another $24 \mathrm{~h}$ incubation. Cells were fixed with $4 \%$ paraformaldehyde in PBS, permeabilised with $0.5 \%$ Triton-X-100 and stained with the anti $\gamma-\mathrm{H} 2 \mathrm{AX}$ antibody from Millipore (JBW301, Millipore, Merck). The primary antibody was detected using anti-mouse AlexaFluor-546 (Invitrogen, Life Technologies). Counterstaining of the nuclei was done using Hoechst 33342 (5 $\mu \mathrm{g} / \mathrm{mL}$, 
Invitrogen, Life Technologies). Images were captured with a Pathway HT Cell Imaging System using the AttoVision image acquisition software (Becton Dickinson) and the fluorescence intensity was quantified per nucleus using the BD Image Data Explorer ${ }^{\mathrm{TM}}$ software.

\section{Rad51 foci staining}

Cells grown on cover slips were washed once with cold PBS and fixed with 4\% para-formaldehyde/ PBS for $10 \mathrm{~min}$. Fixed cells were permeabilised with $0.2 \%$ Triton $\mathrm{X}-100 / \mathrm{PBS}$ on ice for $5 \mathrm{~min}$. The cells were incubated overnight with primary antibodies: mouse monoclonal anti-phospho-S139-H2AX antibody (Millipore) at a dilution of 1:300, mouse monoclonal anti-RAD51 antibody (Abcam 14B4) at a dilution of 1:1000. After being washed three times with cold PBS, the cells were incubated for $1 \mathrm{~h}$ with secondary antimouse Alexa-fluor594 (Invitrogen) at a dilution of 1:500 or anti-rabbit Alexa-fluor488 (Invitrogen) at a dilution of 1:600. The nuclei were counterstained with 4'-6-diamidino-2-phenylindole (DAPI, 10ng/ml). Slides were mounted in Vectashield mounting medium (Vector Laboratories). Immunofluorescence was observed with the Zeiss AxioObserver.Z1 microscope (objectives: ECPlnN 40x/0.75 DICII, resolution $0.44 \mu \mathrm{m}$; Pln Apo 63x/1.4Oil DICII, resolution $0.24 \mu \mathrm{m}$; EC PlnN 100x/1.3 Oil DICII, resolution $0.26 \mu \mathrm{m}$ and filters: Zeiss 43, Zeiss 38, Zeiss 49). Semi-confocal images were obtained using the Zeiss Apotome, Zeiss AxioCamMRm and Zeiss AxioVision Software.

\section{Confocal microscopy (RPA2 staining)}

Cells were grown on cover slips in 6 well plates (Becton Dickinson) for $24 \mathrm{~h}$ and then treated with 5 $\mu \mathrm{M} 5$-FU for $24 \mathrm{~h}$ followed by treatment with $100 \mathrm{ng} /$ $\mathrm{ml}$ NCS. Cells were fixed with $4 \%$ paraformaldehyde in PBS, permeabilised with $0.5 \%$ Triton-X-100 and stained with the anti RPA2 antibody from Calbiochem (NA18, Calbiochem). The primary antibody was detected using anti-mouse IgG antibody coupled to AlexaFluor-488 (Invitrogen, Life Technologies). Counterstaining of the nuclei was done using Hoechst 33342 (5 $\mu \mathrm{g} / \mathrm{mL}$, Invitrogen, Life Technologies). Images were captured with a Carl Zeiss LSM 510 meta confocal microscope (Germany). The RPA2 foci in the nuclei were counted using the FociCounter software (developed by Anna Jucha, University of Wrocław, Poland) http://focicounter. sourceforge.net/.

\section{Expression analysis of $\operatorname{Rad} 51$ and $\mathrm{BRCA2}$ repair genes}

To validate the clinical relevance of our genes, we used an in house generated data set (J. Gaedcke). It is based on 181 rectal tumor biopsies and 181 biopies of matched normal mucosa tissues analysed on Whole Human Genome Microarray 4x44K v2 microarrays. Data were $\log 2$ transformed and normalized using quantile normalization. The genes relevant for this study were extracted from the complete microarray data by gene symbol. In case of multiple probes, expression levels of probes of the same gene were found to be highly correlated, and the highest expressed probe was used. Differential expression was compared on the $\log 2$ differences of tumour vs. mucosa from the same patients, using a one-sample t-test. The data are provided in Supplementary Table 1.

\section{Cell synchronization by double thymidine block}

For synchronization of cell cultures, thymidine (Sigma-Aldrich) was added to the culture medium at a final concentration of $2 \mathrm{mM}$ for $16 \mathrm{~h}$. Thymidine was washed away by adding pre-warmed culture medium to the cells for $5 \mathrm{~min}$ five times. Subsequently, the cells were further incubated for $9 \mathrm{~h}$. A second treatment with $2 \mathrm{mM}$ thymidine for $16 \mathrm{~h}$ was performed. After washing away thymidine as before, the cells were released in fresh culture medium.

\section{RNA extraction and quantitative RT-PCR}

For mRNA analysis, RNA was isolated from cells using TRIzol (Invitrogen/Life Technologies). The isolated RNA was reverse transcribed using 25U M-Mul V Reverse Transcriptase and random hexameric and oligodT primers. For analysis of cDNA samples, SYBR Green (Invitrogen/Life Technologies) was used for quantitative real-time PCR. The following primers were used: GAPDH， 5'-GAAGGTCGGAGTCAACGGATTTG-3' and 5'-CAGAGATGATGACCCTTTTGGCTC-3'; Rad51, 5'-CAACCCATTTCACGGTTAGAGC-3' and 5'-GCTTTGGCTTCACTAATTCCCTT-3'; BRCA2, 5'-GTTGTGAAAAAAACAGGACTTG-3', and 5'-CAGTCTTTAGTTGGGGTGGA-3'. Data were normalized to GAPDH. Relative gene expression was calculated by using the $\Delta \Delta \mathrm{Ct}$ method.

\section{Statistical analysis}

All data are represented as means plus/minus standard error. Unpaired Student's t-test was used for the calculation of $\mathrm{p}$-values. Asterisks indicate significant 
differences $(*, \mathrm{p}<0.05 ; * *, \mathrm{p}<0.01 ; * * *, \mathrm{p}<0.001$ $* * * *, \mathrm{p}<0.0001)$, n.s. $=$ not significant. $n$ in figure legends indicates the number of independent experiments.

\section{CONFLICTS OF INTEREST}

No potential conflicts of interest were disclosed by the authors.

\section{REFERENCES}

1. Shike M, Winawer SJ, Greenwald PH, Bloch A, Hill MJ and Swaroop SV. Primary prevention of colorectal cancer. The WHO Collaborating Centre for the Prevention of Colorectal Cancer. Bull World Health Organ. 1990; 68:377385.

2. Haggar FA and Boushey RP. Colorectal cancer epidemiology: incidence, mortality, survival, and risk factors. Clin Colon Rectal Surg. 2009; 22:191-197.

3. Longley DB, Harkin DP and Johnston PG. 5-fluorouracil: mechanisms of action and clinical strategies. Nat Rev Cancer. 2003; 3:330-338.

4. Mazouzi A, Velimezi G and Loizou JI. DNA replication stress: causes, resolution and disease. Exp Cell Res. 2014; 329:85-93.

5. Dobbelstein $\mathrm{M}$ and Sorensen CS. Exploiting replicative stress to treat cancer. Nat Rev Drug Discov. in press.

6. Di Micco R, Fumagalli M, Cicalese A, Piccinin S, Gasparini P, Luise C, Schurra C, Garre M, Nuciforo PG, Bensimon A, Maestro R, Pelicci PG and d'Adda di Fagagna F. Oncogeneinduced senescence is a DNA damage response triggered by DNA hyper-replication. Nature. 2006; 44:638-642.

7. Bartkova J, Horejsi Z, Koed K, Kramer A, Tort F, Zieger K, Guldberg P, Sehested M, Nesland JM, Lukas C, Orntoft T, Lukas J and Bartek J. DNA damage response as a candidate anti-cancer barrier in early human tumorigenesis. Nature. 2005; 434:864-870.

8. Sampath D, Rao VA and Plunkett W. Mechanisms of apoptosis induction by nucleoside analogs. Oncogene. 2003; 22:9063-9074.

9. Martino-Echarri E, Henderson BR and Brocardo MG. Targeting the DNA replication checkpoint by pharmacologic inhibition of Chk1 kinase: a strategy to sensitize APC mutant colon cancer cells to 5-fluorouracil chemotherapy. Oncotarget. 2014; 5:9889-9900.

10. Dobbelstein M and Moll U. Targeting tumour-supportive cellular machineries in anticancer drug development. Nat Rev Drug Discov. 2014; 13:179-196.

11. Hills SA and Diffley JF. DNA replication and oncogeneinduced replicative stress. Curr Biol. 2014; 24:R435-444.

12. Cimprich KA and Cortez D. ATR: an essential regulator of genome integrity. Nat Rev Mol Cell Biol. 2008; 9:616-627.

13. Matsuoka S, Ballif BA, Smogorzewska A, McDonald ER, 3rd, Hurov KE, Luo J, Bakalarski CE, Zhao Z, Solimini N,
Lerenthal Y, Shiloh Y, Gygi SP and Elledge SJ. ATM and ATR substrate analysis reveals extensive protein networks responsive to DNA damage. Science. 2007; 316:1160-1166.

14. Rogakou EP, Pilch DR, Orr AH, Ivanova VS and Bonner WM. DNA double-stranded breaks induce histone H2AX phosphorylation on serine 139. J Biol Chem. 1998; 273:5858-5868.

15. Adamsen BL, Kravik KL and De Angelis PM. DNA damage signaling in response to 5-fluorouracil in three colorectal cancer cell lines with different mismatch repair and TP53 status. Int J Oncol. 2011; 39:673-682.

16. Falck J, Coates J and Jackson SP. Conserved modes of recruitment of ATM, ATR and DNA-PKcs to sites of DNA damage. Nature. 2005; 434:605-611.

17. Bunting SF, Callen E, Kozak ML, Kim JM, Wong N, Lopez-Contreras AJ, Ludwig T, Baer R, Faryabi RB, Malhowski A, Chen HT, Fernandez-Capetillo O, D'Andrea A and Nussenzweig A. BRCA1 functions independently of homologous recombination in DNA interstrand crosslink repair. Mol Cell. 2012; 46:125-135.

18. Bunting SF, Callen E, Wong N, Chen HT, Polato F, Gunn A, Bothmer A, Feldhahn N, Fernandez-Capetillo O, Cao L, $\mathrm{Xu}$ X, Deng CX, Finkel T, Nussenzweig M, Stark JM and Nussenzweig A. 53BP1 inhibits homologous recombination in Brcal-deficient cells by blocking resection of DNA breaks. Cell. 2010; 141:243-254.

19. Maacke H, Jost K, Opitz S, Miska S, Yuan Y, Hasselbach L, Luttges J, Kalthoff $\mathrm{H}$ and Sturzbecher HW. DNA repair and recombination factor Rad51 is over-expressed in human pancreatic adenocarcinoma. Oncogene. 2000; 19:27912795.

20. Maacke H, Opitz S, Jost K, Hamdorf W, Henning W, Kruger S, Feller AC, Lopens A, Diedrich K, Schwinger E and Sturzbecher HW. Over-expression of wild-type Rad51 correlates with histological grading of invasive ductal breast cancer. Int J Cancer. 2000; 88:907-913.

21. Kauffmann A, Rosselli F, Lazar V, Winnepenninckx V, Mansuet-Lupo A, Dessen P, van den Oord JJ, Spatz A and Sarasin A. High expression of DNA repair pathways is associated with metastasis in melanoma patients. Oncogene. 2008; 27:565-573.

22. Winnepenninckx V, Lazar V, Michiels S, Dessen P, Stas M, Alonso SR, Avril MF, Ortiz Romero PL, Robert T, Balacescu O, Eggermont AM, Lenoir G, Sarasin A, Tursz $\mathrm{T}$, van den Oord JJ and Spatz A. Gene expression profiling of primary cutaneous melanoma and clinical outcome. J Natl Cancer Inst. 2006; 98:472-482.

23. Sarasin A and Kauffmann A. Overexpression of DNA repair genes is associated with metastasis: a new hypothesis. Mutat Res. 2008; 659:49-55.

24. Pierce AJ, Johnson RD, Thompson LH and Jasin M. XRCC3 promotes homology-directed repair of DNA damage in mammalian cells. Genes Dev. 1999; 13:26332638. 
25. Fattah F, Lee EH, Weisensel N, Wang Y, Lichter N and Hendrickson EA. $\mathrm{Ku}$ regulates the non-homologous end joining pathway choice of DNA double-strand break repair in human somatic cells. PLoS Genet. 2010; 6(2):e1000855.

26. Wohlbold L and Fisher RP. Behind the wheel and under the hood: functions of cyclin-dependent kinases in response to DNA damage. DNA repair. 2009; 8:1018-1024.

27. Huang F, Motlekar NA, Burgwin CM, Napper AD, Diamond SL and Mazin AV. Identification of specific inhibitors of human RAD51 recombinase using highthroughput screening. ACS Chem Biol. 2011; 6:628-635.

28. Violette S, Poulain L, Dussaulx E, Pepin D, Faussat A-MM, Chambaz J, Lacorte J-MM, Staedel C and Lesuffleur T. Resistance of colon cancer cells to long-term 5-fluorouracil exposure is correlated to the relative level of Bcl-2 and Bcl$\mathrm{X}(\mathrm{L})$ in addition to Bax and p53 status. Int J Cancer. 2002; 98:498-504.

29. Meyers M, Wagner MW, Hwang HS, Kinsella TJ and Boothman DA. Role of the hMLH1 DNA mismatch repair protein in fluoropyrimidine-mediated cell death and cell cycle responses. Cancer Res. 2001; 61:5193-5201.

30. Morgan MA, Parsels LA, Zhao L, Parsels JD, Davis MA, Hassan MC, Arumugarajah S, Hylander-Gans L, Morosini D, Simeone DM, Canman CE, Normolle DP, Zabludoff SD, Maybaum J and Lawrence TS. Mechanism of radiosensitization by the Chk1/2 inhibitor AZD7762 involves abrogation of the G2 checkpoint and inhibition of homologous recombinational DNA repair. Cancer Res. 2010; 70:4972-4981.

31. Sorensen CS, Hansen LT, Dziegielewski J, Syljuasen RG, Lundin C, Bartek J and Helleday T. The cell-cycle checkpoint kinase Chk1 is required for mammalian homologous recombination repair. Nat Cell Biol. 2005; 7:195-201.

32. Helleday T, Petermann E, Lundin C, Hodgson B and Sharma RA. DNA repair pathways as targets for cancer therapy. Nat Rev Cancer. 2008; 8:193-204.

33. Wyatt MD and Wilson DM. Participation of DNA repair in the response to 5-fluorouracil. Cell Mol Life Sci. 2009; 66:788-799.

34. Bartkova J, Horejsí Z, Koed K, Krämer A, Tort F, Zieger K, Guldberg P, Sehested M, Nesland JM, Lukas C, Ørntoft T, Lukas J and Bartek J. DNA damage response as a candidate anti-cancer barrier in early human tumorigenesis. Nature. 2005; 434:864-870.

35. Connell PP, Jayathilaka K, Haraf DJ, Weichselbaum RR, Vokes EE and Lingen MW. Pilot study examining tumor expression of RAD51 and clinical outcomes in human head cancers. Int J Oncol. 2006; 28:1113-1119.

36. Tennstedt P, Fresow R, Simon R, Marx A, Terracciano L, Petersen C, Sauter G, Dikomey E and Borgmann K. RAD51 overexpression is a negative prognostic marker for colorectal adenocarcinoma. Int J Cancer. 2013; 132:21182126.
37. Nakanoko T, Saeki H, Morita M, Nakashima Y, Ando K, Oki E, Ohga T, Kakeji Y, Toh Y and Maehara Y. Rad51 expression is a useful predictive factor for the efficacy of neoadjuvant chemoradiotherapy in squamous cell carcinoma of the esophagus. Ann Surg Oncol. 2014; 21:597-604. 